\title{
Effect of High-Pressure Processing (HPP) on composition, lactose and microstructure of goat milk
}

\author{
1,* Mustapa Kamal, S.M., ${ }^{1}$ Sulaiman, A. and ${ }^{2}$ Md. Hazmi, N.A. \\ ${ }^{1}$ Department of Process and Food Engineering, Faculty of Engineering, Universiti Putra Malaysia, 43400, \\ Serdang, Selangor, Malaysia. \\ ${ }^{2}$ Food Biotechnology Research Centre, Agro-Biotechnology Institute (ABI), 43400, Serdang, Selangor, \\ Malaysia
}

\author{
Article history: \\ Received: 22 May 2020 \\ Received in revised form: 2 \\ September 2020 \\ Accepted: 25 January 2021 \\ Available Online: 31 January \\ 2021
}

Keywords:

Fat globule,

Goat milk,

High pressure processing,

Lactose,

Microstructure

DOI:

https://doi.org/10.26656/fr.2017.5(S1).050

\begin{abstract}
Thermal pasteurisation is an established method for milk processing. However, the high temperature could affect the micronutrients in the milk. High pressure processing (HPP) is a cold alternative to thermal pasteurisation that can maintain the fresh-like properties of liquid food. However, employing pressure could potentially affect the composition and microstructure of milk and milk products. Therefore, this study focusses on evaluating the effect of high pressure processing (HPP) towards the composition, lactose content and microstructure (in term of fat globules) of goat milk. The goat milk was subjected to HPP at a pressure range of 200 to $600 \mathrm{MPa}$ and process holding time at $5-15$ mins. There were insignificant differences in terms of fat, protein and carbohydrate, but significant changes observed for lactose content of pressurised goat milk (PGM). The lactose content of PGM was in the range of $(2.540-2.986 \mathrm{~g} / \mathrm{mL})$, while $1.253 \pm 0.01 \mathrm{~g} / 100 \mathrm{~mL}$ for untreated goat milk (UGM). A higher number of the small size of goat milk fat globules observed at 600 MPa compared to lower processing pressure (200 and $400 \mathrm{MPa})$ at the same pressure holding time (5 to 15 mins). The mean diameters of fat globules were in the range of 5.215 to $5.651 \mu \mathrm{m}$. This size reduction of milk fat globules is an advantage for cheese making or other dairy product making industries, because it can help to possess a smoother and more refined texture of milk products.
\end{abstract}

\section{Introduction}

Goat milk is widely used in dairy products because it contains many nutritional values, which protein, fat and carbohydrate are the main components (Haenlein, 2004; Kalyankar et al., 2016; Lou et al., 2018). Goat milk becomes familiar to the consumer due to low lactose content but with high protein and high calcium content (Haenlein, 2004; Kalyankar et al., 2016). Hence, goat milk is an excellent alternative to people with lactose intolerant (Zenebe et al., 2014). However, during the processing of dairy products, milk proteins are likely to flocculate and precipitate, which potentially affects the quality of goat milk products (Li et al., 2020). The stability of the milk protein is determined by its structural properties, which are related to the functional properties of the macroscopic structural changes ( $\mathrm{Li}$ et al., 2020). Therefore, functional properties, such as viscosity and texture of milk, could be affected.

In the dairy industry, heat treatment such as high- temperature short time $\left(72^{\circ} \mathrm{C} / 15 \mathrm{~s}\right)$, low-temperature long time $\left(63^{\circ} \mathrm{C} / 30 \mathrm{~min}\right)$, and ultra-high temperature $\left(135^{\circ} \mathrm{C} /\right.$ a few seconds) pasteurisations are standard processing methods used to ensure the safety and providing an extended shelf life of raw milk (Barraquio, 2014). This process eliminates the heat-sensitive raw milk microbiota (Buffa, Trujillo, Pavia et al., 2001). However, this treatment caused damage or changes in the nutrients and altered the structural properties such as the fat globules (Tamime, 2009; Bogahawaththa et al., 2018). Gervilla et al. (2001) reported that in fresh milk, the lipids appear as dispersed milk fat globules. These fat globules which contain 98\% triglycerides are bounded by a membrane that can prevent flocculation and coalescence of fat globules.

Non-thermal processing is gaining more interest in the food industry since it is possible to minimise the changes in terms of nutrient and textural properties of dairy products. High-pressure processing (HPP) is a nonthermal processing method, which an alternative to 
traditional pasteurisation treatment. It has been shown by other authors that HPP provides several advantages to food products either through improvement or maintaining quality and safety (Sulaiman et al., 2017; Evelyn and Silva, 2017; Razali et al., 2019a; Razali et al., 2019b). HPP is a processing method in which the food product is subjected to very high pressure ranging from 100 to $600 \mathrm{MPa}$ (Naik et al., 2013; Moatsou and Park, 2017; Stratakos et al., 2019; Silva and Evelyn, 2020). It is also known as cold pasteurisation since temperature employed in the process is at the ambient range and proven to provide sufficient inactivation towards spoilage microorganisms (Evelyn and Silva, 2015)

HPP potentially affects the coagulation and structural properties of the pressurised milk (Buffa, Trujillo and Guamis, 2001). Together with these changes, the HPP might also modify the fat globules. The fat droplets particle size that presents in dairy products is essential in defining the flavour release, mouthfeel, and emulsion stability (Stratakos et al., 2019). Therefore, it is necessary to clarify the changes in microstructure that is related to goat milk fat globules after HPP. Since the subsequent process that used goat milk for cheese and yoghurt making might be affected due to changes in the milk microstructure. Previous reports also stated that applying the HPP to goat milk and goat milk products can improve milk and product quality - enhance nutrient, flavour and colour retention (Buffa et al., 2001; García et al., 2014). However, a limited study can be found on the HPP effect on the composition and microstructure of goat milk. Thus, the objectives of this study were to investigate the effects of high-pressure processing towards the composition, lactose content, and microstructure of goat milk. Understanding the changes in the microstructure, particularly on the milk fat globules and lactose content of goat milk, will facilitate the production process that involves milk separation and possible to improve the quality of goat milk products.

\section{Materials and methods}

\subsection{Preparation of sample}

Fresh raw goat milk was obtained from a local farm (MFRS Agrofarm) in Selangor, Malaysia. The fresh goat milk was kept in bottles and stored at chilled condition $\left(4^{\circ} \mathrm{C}\right)$. Control samples were held in the refrigerator (at $4^{\circ} \mathrm{C}$ ), while the test samples were treated using High Pressure Processing Unit. Before treatment, milk samples were filled in food-grade plastic pouches (Quiware, Malaysia) and were ensured to remove as much as air possible. These plastic pouches composed of polyethylene and nylon. Each plastic pouch consists of $100 \mathrm{~mL}$ of goat milk. Packed milk samples were then treated in HPP unit with the specified processing conditions, and after treatment, the properties of milk were analysed.

\subsection{High Pressure Processing (HPP) treatment}

The sample pouches with goat milk samples were placed inside the High Pressure Processing Avure 2L700 HPP Laboratory Food Processing System (Avure, USA) with general make up as in Figure 1. The samples were subjected to HPP treatment at a pressure range of 200, 400 and $600 \mathrm{MPa}$; and process holding time of 5, 10 and 15 mins. Temperature for each treatment was set up at $25^{\circ} \mathrm{C}$ (initial temperature). The temperature was indicated by the thermocouple which was equipped with the HPP chamber. The temperature increase due to adiabatic heating caused by pressurisation was noted to be less than $40^{\circ} \mathrm{C}$ for the higher pressure of $600 \mathrm{MPa}$. After the pressurisation process completed, the packed were unloaded and kept in the freezer at $-20^{\circ} \mathrm{C}$ (Hazirah et al., 2018) to stop/slow down any microbiological and biochemical activity until further processing.

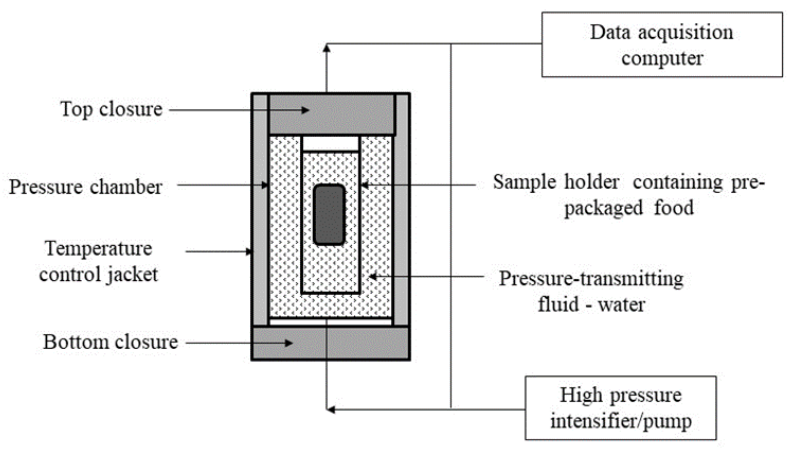

Figure 1. High Pressure Unit configuration set up

\subsection{Proximate analysis}

Proximate analysis was performed for goat milk powder and based on the AOAC method (AOAC, 2000). Moisture content was determined after oven drying at $105^{\circ} \mathrm{C}$ for $8 \mathrm{hrs}$ and ash content was carry out in a furnace at $550^{\circ} \mathrm{C}$ (Muffle Furnace KSL-1700X). The Kjeldahl method was applied to determine protein content with a conversion factor of 6.25. Finally, fat content was carried out by soxhlet extraction (FOSS Soxtec $^{\mathrm{TM}}$ 2050) using hexane as the solvent. Carbohydrate was determined from the difference of moisture, ash, protein, and fat content as described by Equation (1).

Total carbohydrate $=100-$ (weight in grams [protein + fat + water + ash] in $100 \mathrm{~g}$ of sample) 


\subsection{Lactose content}

High-performance liquid chromatography (HPLC) was used to determine the lactose content in goat milk. An analysis column (Phenomenex, Rezex RCM Ca Monosaccharide column) was used in the HPLC system (Agilent Technologies, USA). Pre-degassed distilled water was used as the mobile phase. The samples were injected, and lactose content was detected using an evaporative light scattering detector (ELSD). D-Lactose monohydrate (Sigma-Aldrich, Germany) was used as standard.

\subsection{Scanning electron microscopy (SEM)}

The morphology of the HPP treated and control goat milk powder (without HPP treatment) were observed using Scanning Electron Microscope (SEM) (S-3400N, Hitachi, Japan). Samples were coated with carbon before the examination to avoid charging of specimens and were mounted on the stub for microscopy analysis. The fat globules present in the goat milk powder was analysed from the image generated from the SEM at 3000x magnification. In scanning electron microscopy, an image of the surface of the specimen was obtained. ImageJ (1.52a, NIH, United States) was used to analyse the geometrical properties of the milk fat globules.

\subsection{Statistical Analysis}

Each sample was analysed in duplicate and the data were assessed by analysis of variance (ANOVA) by one way using Minitab 18 (Version 18, Minitab Statistical Software, United States). Evaluations were based on a $5 \%$ significance level $(\mathrm{P}<0.05)$. All the data were presented in mean \pm standard deviation.

\section{Results and discussion}

\subsection{Proximate Analysis}

The proximate analysis was performed after the freeze-drying process (Table 1). The majority of the water contents were removed during freeze-drying. Thus the moisture content of the goat milk was lower value (1.33 to $1.43 \%$ (weight basis)) and the liquid goat milk was transformed to solid goat milk powder. The composition result of the control sample or unpressurised goat milk (UGM) was observed to have fat $(29.35 \%)$, protein $(30.38 \%)$, carbohydrate $(33.43 \%)$, and ash (5.52\%). In comparison with the UGM, the data for fat, protein, ash and carbohydrate of pressurised goat milk (PGM) was slightly changed but statistically insignificant $(p>0.05)$ between pressure treatment ranging from 200 to $600 \mathrm{MPa}$. In general, these results show that either UGM or PGM, both still have high contents of fat, protein and carbohydrate.

The major carbohydrate of goat milk is lactose (Park, 2017), thus high content carbohydrates indicate high lactose content. Lactose is a disaccharide composed of one glucose and one galactose molecules, which a source of nutrition for the human diet. Table 1 shows the lactose content of UGM was $1.253 \pm 0.01 \mathrm{~g} / 100 \mathrm{~mL}$, provide lower value if compared with PGM, in which the differences in lactose content of PGM were significant $(\mathrm{P}<0.05)$. The lactose content for all PGM milk (2.540 $2.986 \mathrm{~g} / \mathrm{mL}$ ) had increased more than double from UGM $(1.253 \pm 0.01 \mathrm{~g} / 100 \mathrm{~mL})$. This condition could induce more lactose content in goat milk after high-pressure treatment. Ferreira et al. (2011) revealed that high pressure (400 MPa) promotes the swelling of cellulose structure which may ease access to glycosidic bonds. The latter shows that high-pressure treatments enhanced the hydrolysis of cellulosic fibre and this could be the reason for the increase of lactose concentration after HPP. The lactose content of PGM that was treated with

Table 1. Composition of Goat Milk Powder

\begin{tabular}{|c|c|c|c|c|c|c|c|c|}
\hline \multirow{2}{*}{$\begin{array}{c}\text { Pressure } \\
(\mathrm{MPa})\end{array}$} & \multirow{2}{*}{$\begin{array}{l}\text { Time } \\
(\operatorname{mins})\end{array}$} & \multicolumn{7}{|c|}{ Composition (Percentage \%) } \\
\hline & & Fat & Protein & Ash & $\begin{array}{c}\text { Moisture } \\
\text { Content }\end{array}$ & $\begin{array}{c}\text { Total } \\
\text { Carbohydrate }\end{array}$ & $\mathrm{pH}$ & $\begin{array}{c}\text { Lactose } \\
(\mathrm{g} / 100 \mathrm{~mL})\end{array}$ \\
\hline \multicolumn{2}{|c|}{ Control } & $29.35 \pm 0.19^{\mathrm{a}}$ & $30.38 \pm 0.19^{\text {abcd }}$ & $5.52 \pm 0.81^{\mathrm{a}}$ & $1.33 \pm 0.03^{\mathrm{a}}$ & $33.43 \pm 1.22^{\mathrm{a}}$ & $6.61 \pm 0.01^{\mathrm{b}}$ & $1.253 \pm 0.01^{\mathrm{e}}$ \\
\hline \multirow[t]{3}{*}{200} & 5 & $32.78 \pm 0.50^{\mathrm{a}}$ & $28.78 \pm 0.67^{\text {bcd }}$ & $5.55 \pm 0.66^{\mathrm{a}}$ & $1.43 \pm 0.02^{\mathrm{a}}$ & $31.46 \pm 0.48^{\mathrm{a}}$ & $6.67 \pm 0.02^{\mathrm{a}}$ & $2.561 \pm 0.01^{\mathrm{d}}$ \\
\hline & 10 & $32.57 \pm 1.99^{\mathrm{a}}$ & $29.14 \pm 0.68^{\mathrm{abcd}}$ & $6.04 \pm 0.07^{\mathrm{a}}$ & $1.38 \pm 0.01^{\mathrm{a}}$ & $30.87 \pm 1.22^{\mathrm{a}}$ & $6.64 \pm 0.01^{\mathrm{ab}}$ & $2.779 \pm 0.04^{b}$ \\
\hline & 15 & $33.80 \pm 0.93^{\mathrm{a}}$ & $28.64 \pm 0.02^{\mathrm{cd}}$ & $5.88 \pm 0.06^{\mathrm{a}}$ & $1.42 \pm 0.11^{\mathrm{a}}$ & $30.27 \pm 0.86^{\mathrm{a}}$ & $6.67 \pm 0.01^{\mathrm{a}}$ & $2.769 \pm 0.03^{b c}$ \\
\hline \multirow[t]{3}{*}{400} & 5 & $33.57 \pm 1.25^{\mathrm{a}}$ & $28.52 \pm 0.59^{d}$ & $6.00 \pm 0.04^{\mathrm{a}}$ & $1.42 \pm 0.01^{\mathrm{a}}$ & $30.50 \pm 1.88^{\mathrm{a}}$ & $6.65 \pm 0.00^{\mathrm{ab}}$ & $2.540 \pm 0.02^{\mathrm{d}}$ \\
\hline & 10 & $31.30 \pm 1.79^{\mathrm{a}}$ & $30.79 \pm 0.26^{\mathrm{a}}$ & $6.06 \pm 0.12^{\mathrm{a}}$ & $1.39 \pm 0.04^{\mathrm{a}}$ & $30.46 \pm 1.61^{\mathrm{a}}$ & $6.68 \pm 0.00^{\mathrm{a}}$ & $2.797 \pm 0.00^{\mathrm{b}}$ \\
\hline & 15 & $30.80 \pm 1.99^{\mathrm{a}}$ & $30.57 \pm 0.07^{\mathrm{a}}$ & $5.59 \pm 0.69^{\mathrm{a}}$ & $1.40 \pm 0.08^{\mathrm{a}}$ & $31.63 \pm 1.46^{\mathrm{a}}$ & $6.65 \pm 0.01^{\mathrm{ab}}$ & $2.797 \pm 0.02^{\mathrm{b}}$ \\
\hline \multirow[t]{3}{*}{600} & 5 & $30.13 \pm 1.88^{\mathrm{a}}$ & $31.06 \pm 0.60^{\mathrm{a}}$ & $5.74 \pm 0.36^{\mathrm{a}}$ & $1.35 \pm 0.03^{\mathrm{a}}$ & $31.73 \pm 0.88^{\mathrm{a}}$ & $6.66 \pm 0.00^{\mathrm{a}}$ & $2.679 \pm 0.02^{\mathrm{c}}$ \\
\hline & 10 & $30.35 \pm 2.49^{\mathrm{a}}$ & $30.56 \pm 0.09^{\mathrm{ab}}$ & $5.55 \pm 0.77^{\mathrm{a}}$ & $1.34 \pm 0.05^{\mathrm{a}}$ & $32.19 \pm 1.76^{\mathrm{a}}$ & $6.65 \pm 0.01^{\mathrm{ab}}$ & $2.895 \pm 0.03^{\mathrm{a}}$ \\
\hline & 15 & $31.98 \pm 2.88^{\mathrm{a}}$ & $30.51 \pm 0.78^{\mathrm{abc}}$ & $5.51 \pm 0.75^{\mathrm{a}}$ & $1.36 \pm 0.04^{\mathrm{a}}$ & $30.64 \pm 1.39^{\mathrm{a}}$ & $6.65 \pm 0.01^{\mathrm{ab}}$ & $2.986 \pm 0.01^{\mathrm{a}}$ \\
\hline
\end{tabular}

Values are expressed as mean $\pm \mathrm{SD}, \mathrm{n}=2$. Values with the different superscript within the same column are significantly different among treatments $(\mathrm{P}<0.05)$. 
three different pressure (200 to $600 \mathrm{MPa}$ ) at 5 mins holding time showed significant difference $(\mathrm{P}<0.05)$ as compared with a sample treated at the same pressure but at different holding time. For holding time of 10 and 15 mins, the results of lactose content showed no significant difference $(\mathrm{P}>0.05)$ at the same pressure. The highest lactose content among PGM samples was at $600 \mathrm{MPa}$ for 15 mins with a value of $2.986 \pm 0.01 \mathrm{~g} / 100 \mathrm{~mL}$. While the lowest lactose content $(2.561 \pm 0.01 \mathrm{~g} / 100 \mathrm{~mL})$ for PGM was at condition treated with $200 \mathrm{MPa}$ for 5 mins.

$\mathrm{pH}$ value for UGM was 6.61, which not much different and in the range of $\mathrm{pH}$ data of goat milk reported by a previous researcher (Park et al., 2007). The $\mathrm{pH}$ value for $\mathrm{PGM}$ was slightly higher $(\mathrm{P}<0.05)$ as compared with UGM, with the average $\mathrm{pH}$ value ranging from 6.64 to 6.68 for all conditions treated by high pressure. However, overall differences in the $\mathrm{pH}$ were not significant $(\mathrm{P}>0.05)$ for all milk samples treated with high pressure. High pressure treatment might be possible to cause an increase in the concentration of calcium ion in milk due to calcium release from casein micelles immediately after treatment (Zobrist et al., 2005; Cadesky et al., 2017), which causes the increase in the milk $\mathrm{pH}$.

\subsection{Analysis of the microstructure}

The microstructure of unpressurised goat milk (UGM) and pressurised goat milk (PGM) treated at 200 - $400 \mathrm{MPa}$ are shown in Figures 2 to 5. From the micrographs obtained from SEM, the average geometrical parameter values of goat's milk fat globules were analysed and shown in Table 2. The milk fat globules of UGM were smooth, remained intact, no burst or cleavage had been observed (Figure 2). The average diameter of UGM fat globules was found $6.126 \pm 0.609$ $\mu \mathrm{m}$ with a surface area was $33.908 \pm 4.619 \mu \mathrm{m}^{2}$. The diameter of UGM fat globules in this study is larger than $3.49 \mu \mathrm{m}$ reported by Park et al. (2007). Raw goat milk's fat globule had a spherical structure with a roundness of $87.7 \%(0.877 \pm 0.099)$ with some of the fat globules coalesced.

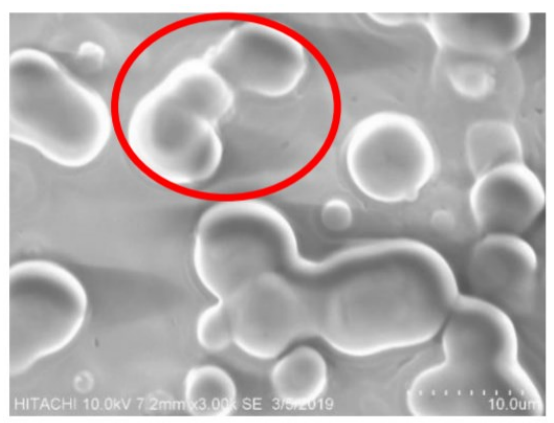

Figure 2. Microstructure of untreated goat milk in a red circle (larger compared to after HPP) at 3000x magnification.

The microstructure of PGM treated with $200 \mathrm{MPa}$ for 5-15 mins are shown in Figure 3. The average diameter of PGM treated at $200 \mathrm{MPa}$ decreased when the holding time increased with values of $7.136 \pm 2.175 \mu \mathrm{m}$ (5 mins.), $6.176 \pm 2.255 \mu \mathrm{m}$ (10 mins), and $5.894 \pm 1.624$ $\mu \mathrm{m}$ (15 mins). Compared with UGM, the diameter of PGM treated at $200 \mathrm{MPa}$ for 5 and 10 mins were slightly increased. At 5 mins (Figure 3a), the fat globules not fission but tend to aggregates. At 10 mins (Figure 3b), there were distortions of fat globules with smaller fat globules observed and also coalesced between fat globules. Prolonged holding time to 15 mins (Figure 3c), small size fat globules were observed as compared to UGM. At this condition (200 MPa for 15 mins.), might be enough time for fat globules to fission into a smaller size $(5.894 \pm 1.624 \mu \mathrm{m})$ and disaggregate. In term of shape, the PGM's fat globules (treated at $200 \mathrm{MPa}$ for 5 mins) had more towards oval shape with an average roundness of $79.8 \%(0.798 \pm 0.051)$ as compared to the others pressurised treated condition of $10 \mathrm{~min}(86.4 \%)$; 15 mins (89\%) and UGM (87.7\%).

Table 2. Average geometrical parameter values of goat's milk fat globules

\begin{tabular}{ccccc}
\hline \multirow{2}{*}{$\begin{array}{c}\text { Pressure } \\
(\mathrm{MPa})\end{array}$} & $\begin{array}{c}\text { Time } \\
(\text { mins })\end{array}$ & \multicolumn{3}{c}{ Geometrical Properties } \\
\cline { 3 - 5 } & Diameter $(\mu \mathrm{m})$ & Roundness & Area $\left(\mu \mathrm{m}^{2}\right)$ \\
\hline \multicolumn{2}{c}{ Control } & $6.126 \pm 0.609$ & $0.877 \pm 0.099$ & 33.908 \\
\hline 200 & 5 & $7.136 \pm 2.175$ & $0.798 \pm 0.051$ & 49.206 \\
& 10 & $6.176 \pm 2.255$ & $0.864 \pm 0.090$ & 44.044 \\
& 15 & $5.894 \pm 1.634$ & $0.890 \pm 0.049$ & 43.512 \\
\hline 400 & 5 & $8.300 \pm 2.830$ & $0.830 \pm 0.061$ & 64.181 \\
& 10 & $6.805 \pm 1.226$ & $0.814 \pm 0.071$ & 43.321 \\
& 15 & $10.066 \pm 1.624$ & $0.694 \pm 0.071$ & 74.779 \\
\hline 600 & 5 & $5.397 \pm 0.750$ & $0.859 \pm 0.091$ & 24.627 \\
& 10 & $5.215 \pm 1.070$ & $0.876 \pm 0.109$ & 22.310 \\
& 15 & $5.651 \pm 2.228$ & $0.879 \pm 0.119$ & 25.032 \\
\hline
\end{tabular}

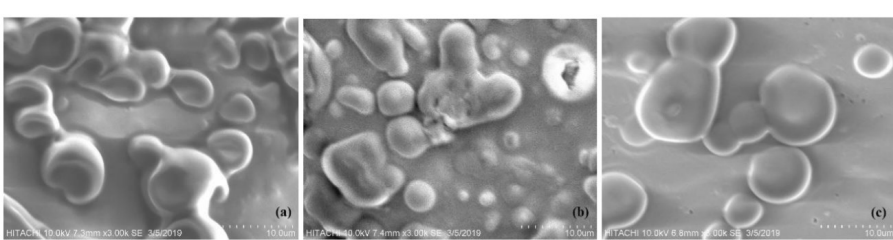

Figure 3. Microstructure of goat milk treated with $200 \mathrm{MPa}$ for (a) 5 mins, (b) 10 mins, (c) 15 mins at 3000x magnification

At high pressure processing of $400 \mathrm{MPa}$, varying diameter size for fat globules of PGM were observed when the holding time prolonged from 5 -15 mins (Figure $4 \mathrm{a}-\mathrm{c}$ ). The size of fat globules was observed to be larger $(8.300 \pm 2.830 \mu \mathrm{m})$ at holding time of $5 \mathrm{mins}$, then decreased to $6.805 \pm 1.226 \mu \mathrm{m}(10 \mathrm{mins})$ and finally at longer holding time (15 mins) the size increased to $10.066 \pm 1.624 \mu \mathrm{m}$. At 10 mins of holding time, smaller globules were observed, which might occur due to the fission of fat globules. However, at longer holding time (15 mins) smaller globule might coalesce (aggregate) together resulted in an increase in the size of fat globules. The fat globules size results also correlated 
with the shape (roundness) of fat globules, which varies distributed with $83 \%$ (5 mins), $81.4 \%$ (10 mins), and $69.4 \%$ (15 mins). Compared with UGM, the diameter size for all fat globules treated at $400 \mathrm{MPa}$ with 5 - 15 mins were larger, and similarly with results of surface area that also given highest values $\left(64.181 \pm 34.428 \mu \mathrm{m}^{2}\right.$ (5 mins); $43.321 \pm 14.188 \mu \mathrm{m}^{2}$ (10 mins); $74.779 \pm 21.307$ $\mu \mathrm{m}^{2}$ (15 mins)).

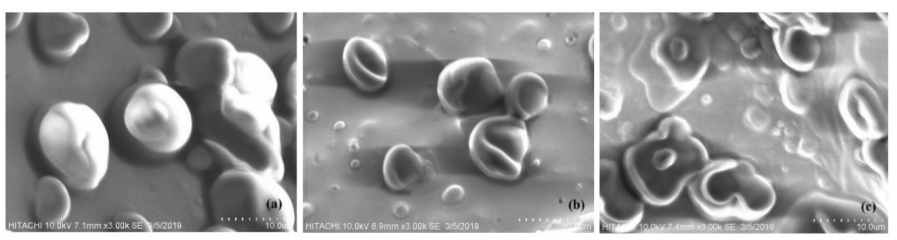

Figure 4. Microstructure of goat milk treated with $400 \mathrm{MPa}$ for (a) 5 mins, (b) 10 mins, (c) 15 mins at 3000x magnification.

Figure 5 (a-c) shows the microstructure of PGM treated at $600 \mathrm{MPa}$ from $5-15$ mins of holding time. The diameter of fat globules of PGM treated at $600 \mathrm{MPa}$ for all holding time (5 - 15 mins) were similar in size with a diameter of $5.397 \pm 0.750 \mu \mathrm{m} \quad(5$ mins $)$, $5.215 \pm 1.070 \mu \mathrm{m}(10 \mathrm{mins})$ and $5.651 \pm 2.228 \mu \mathrm{m}(15$ mins), respectively (Table 1). Stable globular structure of fat globules was observed at 5 mins (Figure 5a), while at 15 mins (Figure 5c) slightly aggregation of fat globules been observed. At the highest pressurised condition (600 $\mathrm{MPa}$ ), the fat globules fission into smaller sizes and the size were smaller as compared to PGM treated at 200 and $400 \mathrm{MPa}$. Serra et al. (2007) had studied high pressurised treated (100 to $330 \mathrm{MPa}$ ) of cow milk, which they also observed fat globules reduction as compared to raw cow milk. Gervilla et al. (2001) found slight changes in milk fat globules of ewe's milk which were pressurised between 100 to $500 \mathrm{MPa}$, with the average diameter size of fat globules of pressurised milk ranges from 4.3 to $5.1 \mu \mathrm{m}$ and the unpressurised fat globules were $5.0 \mu \mathrm{m}$. In general, the use of HPP contributes to the homogenisation of milk products through a reduction of fat globule size, which with smaller globules cannot form large enough clusters for creaming to occur; causing an increase of milk shelf-life (Stratakos et al., 2019).

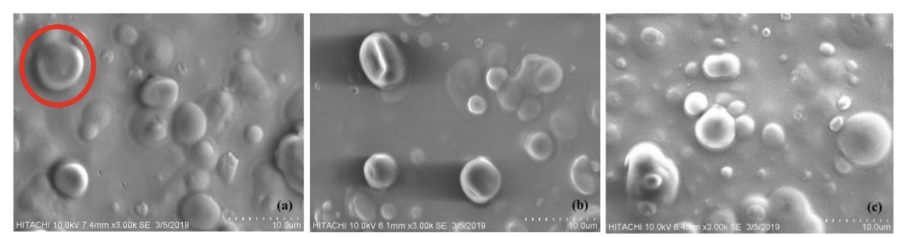

Figure 5. Microstructure of goat milk treated with $600 \mathrm{MPa}$ for (a) 5 mins, (b) 10 mins, (c) 15 mins at 3000x magnification. Smallest compared (red circle) to raw, $200 \mathrm{MPa}$ and $400 \mathrm{MPa}$.

The results for surface areas of PGM treated at 600 $\mathrm{MPa}$ ranging from $24.627 \pm 8.168 \mu^{2}$ (5 mins), $22.310 \pm 14.084 \mu \mathrm{m}^{2}(10 \mathrm{mins})$ and $25.032 \pm 19.808 \mu \mathrm{m}^{2}$ (15 mins) were lower as compared with UGM
(33.908 $\left.\pm 4.619 \mu \mathrm{m}^{2}\right)$. However, the shape (roundness) of the PGM fat globules were more roundness (85.9-87.9\%) and smooth, which not much differences with UGM roundness $(87.7 \%)$. In general, smaller fat globules will improve the dispersion and more homogeneous mixture of fat in goat milk that would offer lipases with a larger surface area of fat for greater digestive action (Park, 2017).

\section{Conclusion}

High pressure processing of goat milk caused significant changes to milk's protein, fat, and carbohydrate compositions. Lactose content increased more than double after pressurised treatment as compared to untreated milk. Pressurised goat milk show no significant changes to the $\mathrm{pH}$ of treated milk $(\mathrm{P}<0.05)$. In term of morphological size of fat globules, two opposing effects were observed. The diameter size of fat globule for goat milk treated below $400 \mathrm{MPa}$ appears to increase as compared with untreated goat milk. While the size of fat globules were seen to decrease after pressurisation at $600 \mathrm{MPa}$ compared to untreated milk showing evidence of fat globules fission. The size reduction of milk fat globules provides advantages in cheese or other dairy product making industries that possible to possess smoother and finer texture for the goat milk products.

\section{Acknowledgements}

The authors acknowledge the Universiti Putra Malaysia for the support on research facilities, chemicals and consumables and to the Department of Food Biotechnology, Agro-Biotechnology Institute (ABI), Malaysia for allowing us to use the high pressure unit.

\section{References}

Barraquio, V.L. (2014). Which milk is fresh. International Journal of Dairy Science and Processing, 1(2), 1-6. https://doi.org/10.19070/23791578-140002

Bogahawaththa, D., Buckow, R., Chandrapala, J. and Vasiljevic, T. (2018). Comparison between thermal pasteurisation and high pressure processing of bovine skim milk in relation to denaturation and immunogenicity of native milk proteins. Innovative Food Science and Emerging Technologies, 47, 301308. https://doi.org/10.1016/j.ifset.2018.03.016

Buffa, M., Trujillo, A.J. and Guamis, B. (2001). Rennet coagulation properties of raw, pasteurised and high pressure-treated goat milk. Milchwissenschaft, 56(5), 243-246.

Buffa, M.N., Trujillo, A.J., Pavia, M. and Guamis, B. 
(2001). Changes in textural, microstructural, and colour characteristics during ripening of cheeses made from raw, pasteurized or high-pressure-treated goats' milk. International Dairy Journal, 11(11-12), 927-934. https://doi.org/10.1016/S0958-6946(01) 00141-8

Cadesky, L., Walkling-Ribeiro, M., Kriner, K.T., Karwe, M.V. and Moraru, C.I. (2017). Structural changes induced by high-pressure processing in micellar casein and milk protein concentrates. Journal of Dairy Science, 100(9), 7055-7070. https:// doi.org/10.3168/jds.2016-12072

Evelyn and Silva F.V.M. (2017). Inactivation of Pathogenic Microorganisms in Foods by High Pressure Processing. In Rai, V.R. and Bai, J.A. (Eds). Food Safety and Protection, p. 341-377. USA: CRC Press. https://doi.org/10.1201/978131515341410

Evelyn and Silva, F.V.M. (2015). High pressure processing of milk: Modeling the inactivation of psychrotrophic Bacillus cereus spores at $38-70^{\circ}$ C. Journal of Food Engineering, 165, 141-148. https://doi.org/10.1016/j.jfoodeng.2015.06.017

Ferreira, A.R., Figueiredo, A B., Evtuguin, D.V. and Saraiva, J.A. (2011). High pressure pre-treatments promote higher rate and degree of enzymatic hydrolysis of cellulose. Green Chemistry, 13(10), 2764-2767. https://doi.org/10.1039/c1gc15500h

García, V., Rovira, S., Boutoial, K. and López, M.B. (2014). Improvements in goat milk quality: A review. Small Ruminant Research, 121(1), 51-57. https://doi.org/10.1016/j.smallrumres.2013.12.034

Gervilla, R., Ferragut, V. and Guamis, B. (2001). High hydrostatic pressure effects on color and milk-fat globule of ewe's milk. Journal of Food Science, 66 (6), 880-885. https://doi.org/10.1111/j.13652621.2001.tb15190.x

Haenlein, G.F.W. (2004). Goat milk in human nutrition. Small ruminant research, 51(2), 155-163. https://doi.org/10.1016/j.smallrumres.2003.08.010

Hazirah, S., Jaafar, S., Hashim, R., Hassan, Z. and Arifin, N. (2018). A Comparative Study on Physicochemical Characteristics of Raw Goat Milk Collected from Different Farms in Malaysia. Tropical Life Sciences Research, 29(1), 195-212. https://doi.org/10.21315/tlsr2018.29.1.13

Kalyankar, S.D., Khedkar, C.D. and Patil, A.M. (2016) Goat: Milk. In Caballero, B., Finglas, P.M. and Toldrá, F. (Eds), Encyclopaedia of Food and Health, p. 256-260. Amsterdam: Elsevier. https:// doi.org/10.1016/B978-0-12-384947-2.00358-5

Li, X.Y., Cheng, M., Li, J., Zhao, X., Qin, Y.S., Chen,
D., Wang, J.M. and Wang, C.F. (2020). Change in the structural and functional properties of goat milk protein due to $\mathrm{pH}$ and heat. Journal of Dairy Science, 103(2), 1337-1351. https://doi.org/10.3168/ jds.2019-16862

Lou, X., Li, J., Zhang, X., Wang, J. and Wang, C. (2018). Variations in fatty acid composition of Laoshan goat milk from partum to 135 days postpartum. Animal Science Journal, 89(11), 16281638. https://doi.org/10.1111/asj.13098

Moatsou, G. and Park, Y.W. (2017). Goat milk products: Types of products, manufacturing technology, chemical composition, and marketing. In Park, Y.W., Haenlein, G.F.W. and Wendoff,W.L (Eds.), Handbook of Milk of Non-Bovine Mammals, p. 84149. John Wiley and Sons. https:// doi.org/10.1002/9781119110316.ch2.3

Naik, L., Sharma, R., Rajput, Y.S. and Manju, G. (2013). Application of high pressure processing technology for dairy food preservation-future perspective: A review. Journal of Animal Production Advances, 3 (8), 232-241. https://doi.org/10.5455/ japa.20120512104313

Park, Y.W., (2017). Goat milk-chemistry and nutrition. In Park, Y.W., Haenlein, G.F.W. and Wendoff, W.L (Eds.), Handbook of Milk of Non-Bovine Mammals, p. 42-83. United Kingdom: John Wiley and Sons. https://doi.org/10.1002/9781119110316.ch2.2

Park, Y.W., Juárez, M., Ramos, M. and Haenlein, G.F.W. (2007). Physico-chemical characteristics of goat and sheep milk. Small Ruminant Research, 68(1 -2), 88-113. https://doi.org/10.1016/ j.smallrumres.2006.09.013

Razali, M.F., Mohd Fauzi, N.A., Sulaiman, A., Talip, B.A. and Rahman, A.A. (2019a). Effect of highpressure processing on prebiotic potential of stingless bee (Kelulut) honey: Tested upon Lactobacillus acidophilus and Lactobacillus brevis. Journal of Food Processing and Preservation, 43(7), e13946. https://doi.org/10.1111/ jfpp.13946

Razali, M.F., Fauzi, N.A.M., Sulaiman, A. and Rahman, N.A.A. (2019b). Effect of high-pressure processing (HPP) on antioxidant, diastase activity and colour for kelulut (stingless bee) honey. Jurnal Teknologi, 81 (3), 91-98. https://doi.org/10.11113/jt.v81.13105

Serra, M., Trujillo, A.J., Quevedo, J.M., Guamis, B. and Ferragut, V. (2007). Acid coagulation properties and suitability for yogurt production of cows' milk treated by high-pressure homogenisation. International Dairy Journal, 17(7), 782-790. https://doi.org/10.1016/ j.idairyj.2006.10.001 
Silva, F.V.M. (2020). Resistant moulds as pasteurization target for cold distributed high pressure and heat assisted high pressure processed fruit products. Journal of Food Engineering, 282, 109998 . https://doi.org/10.1016/ j.jfoodeng.2020.109998

Stratakos, A.C., Inguglia, E.S., Linton, M., Tollerton, J., Murphy, L., Corcionivoschi, N., Koidis, A. and Tiwari, B.K. (2019). Effect of high pressure processing on the safety, shelf life and quality of raw milk. Innovative Food Science and Emerging Technologies, 52, 325-333. https://doi.org/10.1016/ j.ifset.2019.01.009

Sulaiman, A., Farid, M. and Silva, F.V.M. (2017). Strawberry puree processed by thermal, high pressure, or power ultrasound: Process energy requirements and quality modeling during storage. Food Science and Technology International, 23(4), 293-309. https:// doi.org/10.1177/1082013216685485

Tamime, A.Y. (Ed). (2009). Milk processing and quality management. United Kingdom: John Wiley and Sons. https://doi.org/10.1002/9781444301649

Zenebe, T., Ahmed, N., Kabeta, T. and Kebede, G. (2014). Review on medicinal and nutritional values of goat milk. Academic Journal of Nutrition, 3(3), 30 -39 .

Zobrist, M.R., Huppertz, T., Uniacke, T., Fox, P.F. and Kelly, A.L. (2005). High-pressure-induced changes in the rennet coagulation properties of bovine milk. International Dairy Journal, 15(6-9), 655-662. https://doi.org/10.1016/j.idairyj.2004.07.025 